\title{
IMPROVING STUDENTS' SPEAKING ABILITY THROUGH NUMBERED HEADS TOGETHER STRATEGY AT GRADE XI SMA N 1 BATANG ANGKOLA
}

By: Zainuddin, M.Hum., Sojuangon Rambe, S.S., M.Pd., and Maria

\begin{abstract}
ABSTRAK
Penelitian ini bertujuan untuk meningkatkan kemampuan berbicara siswa kelas XI SMA Negeri 1 Batang Angkola pada Tahun Akademik 2017/2018 melalui Strategi. Penelitian dilakukan untuk memecahkan masalah siswa dalam kemampuan berbicara. Tujuan dari penelitian ini adalah untuk mendeskripsikan peningkatan kemampuan berbicara siswa melalui strategi nomor urut di kelas XI SMA N 1 Batang Angkola dan untuk mengetahui faktor-faktor yang mempengaruhi kemampuan berbicara siswa melalui strategi nomor urut bersama pada kelas XI SMA N 1 Batang Angkola. Penelitian ini dikategorikan menjadi penelitian tindakan yang terdiri dari dua siklus. Berdasarkan hasil penelitian, peneliti menemukan bahwa kemampuan berbicara siswa meningkat. Hal ini didukung oleh hasil pada siklus 1 yaitu 66,09 (21,74\%) dan pada siklus 2 adalah 77,91 (73,91\%). Jadi, peningkatan kemampuan berbicara siswa dengan menggunakan strategi Numbered Heads Together adalah kategori yang tinggi. Kemudian, beberapa faktor yang mempengaruhi kemampuan berbicara melalui strategi bernomor bersama adalah sebagian besar siswa sulit mengucapkan katakata, kata-kata siswa sulit untuk membangun kata-kata, siswa sulit untuk mencari kata-kata yang memadai, siswa sulit untuk berbicara bahasa Inggris dengan lancar dan siswa sulit untuk memahami kata-kata.
\end{abstract}

Kata Kunci: Kemampuan berbicara dan Strategi Numbered Head Together

\section{A. Background of the Study}

Speaking is one of language skills in which the function as the students' target language as communication tool. Speaking is the process of building and sharing meaning thought in verbal and symbol of varieties in context. Speaking has some of significances in our life. Speaking is to express the idea. Speaking is one way that often used and more understandable to communicate. It is known speak to share and express our thoughts, feeling, opinion, and desires. When someone speaks something, they will interact and use the language to transfer idea. It is known that express our thought and felling by speaking. Therefore, it can transfer 
to other people about opinion. Speaking is important to be learned mastered by every individual. Speakers use language to communicate to others, and the interaction has the purpose of influencing the listeners.

The researcher interested to choose numbered heads together to improve the students' speaking ability. Because, numbered heads together is training and asking the students to create a same perception in the group, and numbered heads together can create students creativity in thinking. Such as, the research of Identit Vigur Prasetyo in Department of English Education ${ }^{1}$. He said that Numbered Heads Together was applied in the teaching and learning process could encourage the students to be confident in speaking English. NHT accommodates the students with the group discussion before they perform independently. It helps them to make their performances better. Through the discussion with their friends, the students could have opportunities to communicate interactively and share their comprehension about the learning materials. Therefore, the Numbered Heads Together strategy is very beneficial to be implemented in the teaching and learning process, especially speaking.

By looking at discussion above, the researcher believed the important of conducting a classroom action research which purpose to improve students' speaking ability. the researcher was interested to choose the location at SMA N 1 Batang Angkola that is with the topic.“'Improving Students' Speaking Ability Through Numbered Heads Together Strategy at Grade XI IPA-1 in First Semester of the Academic Year 2017/2018 SMA N 1 Batang Angkola”.

\section{B. The Purpose of the Research}

Based on the formulation of the problem above, the purpose of the research as follow:

1. To describe the improvement of students' speaking ability through numbered heads together at grade XI SMA N 1 Batang Angkola

2. To identify the factors which influence students' speaking ability through numbered heads together at grade XI SMA N 1 Batang Angkola

\footnotetext{
${ }^{1}$ Vigur Prasetiyo, "Improving Speaking Skill of Grade VIII B Students of SMP Negeri 1 Jogonalan through Numbered Heads Together Strategy in the Academic Year of 2014/2015", (UniversitasNegeri Yogyakarta, 2015), p. 84. http://mjal.org/journal/coop.pdf retrived on November $23^{\text {rd }}$ 2016 at $10.00 \mathrm{pm}$.
} 


\section{Hypothesis of Action}

The hypothesis of action in this research is stated that: "Numbered Heads Together can improve students speaking ability at SMA N 1 Batang Angkola”.

\section{Theoretical Description}

\section{The Theory Description of Speaking Ability}

\section{a. Definition of Speaking Ability}

Speaking is proposed to express idea. Speaking is to express or communication opinions, feeling, ideas, and experience. It involves the activities in the part of speaker as psychological, articulator, and physical stages. Speaking can be called as oral communication and speaking is one of the important subjects that the students should be mastered. Webster New World Collage Dictionary said that speaking is the act or art of the person who speaks that which is spoken, utterance, discourse. ${ }^{2}$

Based on the definition above can be concluded that speaking is the process of communication to express, inform, and gives the idea, knowledge, feeling, thought, opinion and experience by using sounds of articulation that can be learn through teaching and learning process.

\section{b. The Principles for Designing Speaking in Teaching Speaking}

There are 7 principles to use as guide for teaching speaking, as follow:

1) Techniques could cover the spectrum of learner needs, from language-based focus on accuracy to message- based focus on interaction, meaning and fluency. When you do a technique, make sure that task includes technique designed to help students to perceive and use the building blocks of language.

2) Techniques should be intrinsically motivating. Try all time to appeal to students' ultimate goals and interest, to their need for knowledge, for status, for achieving competence, autonomy and for being all that they can be. Even in those techniques that don't send students into ecstasy, help them to see how the activity will benefit them.

3) Techniques could encourage the use of authentic language in meaningful contexts.

\footnotetext{
${ }^{2}$ Victoria Neufeldt, Webter New Collage Dictionary-3 rd, (New York: Simon \&SchuterIne, 1995), p. 1217.
} 
4) Provide appropriate feedback and correction. The students are totally dependent on the teacher for useful linguistic feedback, they may get such feedback out there beyond the classroom, but even then you are in a position to be of great benefit. It is important that you take advantage of your knowledge of English to inject the kinds of corrective feedback that are appropriate for the moment.

5) Capitalize on the natural link between speaking and listening.

6) Give students opportunities to initiate oral communication.

7) Encourage the development of speaking strategies. The concept of strategies competence is one that few beginning language students are aware of. They simply have not thought about developing their own personal strategies for accomplishing oral communicative purposes. ${ }^{3}$

From the explanation above, that is concluded that there are some principles for designing speaking in teaching speaking. So, teacher is better to apply that are principles for designing in teaching speaking.

\section{c. Speaking Evaluation}

Oxford Advance Learner's Dictionary states that Evaluation is decide on the value or quality of something. ${ }^{4}$ Evaluation is a manner of judging the fitness of something for particular purposes.

\section{Table 1}

\section{Indicators of Speaking Evaluation}

\begin{tabular}{|c|l|}
\hline NO & Indicators of Speaking Evaluation \\
\hline 1 & Able to produce reduced forms of words and phrases \\
\hline 2 & Able to produce fluent speech at different rates of delivery \\
\hline 3 & $\begin{array}{l}\text { Able to express a particular meaning in different grammatical } \\
\text { forms }\end{array}$ \\
\hline 4 & Able to performance \\
\hline
\end{tabular}

Arthur Hughes states that there are five categories to measure speaking skill as follow:

1) Accent

The term accent is used to refer to the speech of someone who speaks a language non-natively. The accent can be identifying as

\footnotetext{
${ }^{3}$ Jack. C. Richards, curriculum development in language teaching, (New York: Cambridge University Press), p. 221.

${ }^{4}$ Victoria Bull, Oxford Advance Learner's Dictionary Sixth Edition,(New York: Oxford University Press, 2008), p.151.
} 
follow:pronunciation frequently unintelligible, frequent gross errors and a very heavy accent make understanding difficult, foreign accent requires concentrated listening and mispronunciation lead to occasional misunderstanding and apparent errors in grammar and vocabulary, marked foreign accent and occasional mispronunciation, which do not interfere with understanding, native pronunciation, with no trace of foreign accent.

2) Grammar

Grammar is the part of study of language which deals with the form and structure of word (morphology), with their customary arrangement in phrase and sentence (syntax), and how often with language sound (phonology), and word meaning (semantic). In other words, grammar tells us how to construct a sentence. Grammar can be identifying as follow: grammar almost entirely inaccurate phrases, constant errors showing of very few major patterns and frequently preventing communication, frequent errors showing some major patterns uncontrolled and causing occasional irritation and misunderstanding, occasional errors showing imperfect control of some patterns but not weakness that causes misunderstanding, few errors, with no pattern of failure, no more than two errors during the interview.

3) Vocabulary

Vocabulary is more that a list of target language of words. Vocabulary can identified look like: vocabulary limited to basic personal and survival areas (time, food, transportation, and family), choice of word sometimes inaccurate, limitation of vocabulary prevents discussion of some common professional and social topics, professional vocabulary adequate to discuss special interest; general vocabulary permits discussion on any non-technical subjects with some circumlocution, professional vocabulary broad and precise; general vocabulary adequate to cope with complex practical problems 
and varied social Situations, vocabulary apparently as accurate and extensive as that of an educated native speaks.

4) Fluency

Fluency is probably best achieved by following the steam of speech to flow then as some of over beyond comprehensibility the rivers bank of instruction on some detail of phonology, grammar or discourse will channel the speech on more purposeful course.

Fluency can be identifying as follow: Speech is no halting and fragmentary that conversation is virtually impossible, speech is very slow and uneven except for short or routine sentences, speech is frequently hesitant and jerky: sentence may be left uncompleted, speech is occasionally hesitant with some unevenness caused by rephrasing and grouping for words, speech is effortless and smooth but perceptibly nonnative in speed and evenness, speech on all professional and general topics as effortless and smooth as a native speaker's.

5) Comprehension

Comprehension is the mind's act or power of understanding. Comprehension is the capacity for understanding ideas, fact, etc. a longer definition of comprehension will be as the act of understanding the meaning. Comprehension can be identifying as follow: Understand too little for the simplest types of conversation, understand only slow, very simple speech on common social and tourist topics; requires constant repetition and rephrasing, understand careful, somewhat simplified speech when engaged in a dialogue but may require considerable repetition and rephrasing, understand quite well normal educated speech when engaged in a dialogue but requires occasional repetition and rephrasing, understands everything in normal educated conversation except for very colloquial or low-frequency items, or exceptionally rapid or slurred speech, understands everything in both 
formal and colloquial speech to be expected of an educated native speaker 5 .

Based on the explanation above, it can be concluded that there are five categories to measure speaking skill, they are: accent, grammar, fluency, vocabulary, and comprehension.

\section{The Theory Description of Numbered Heads Together}

\section{a. Definition of Numbered Heads Together}

Kagan states that "Number Head Together (NHT) is a simple four-step structure. Its main strengths are in building mastery and in reviewing previously learned information". Numbered Heads Together is a cooperative learning strategy that holds each student accountable for learning the material. Students are placed in groups and each person is given a number (from one to the maximum number in each group). ${ }^{6}$ The teacher poses a question and students "put their heads together" to figure out the answer. The teacher calls a specific number to respond as spokesperson for the group. By having students work together in a group, this strategy ensures that each member knows the answer to problems or questions asked by the teacher. Because no one knows which number will be called, all team members must be prepared.

So, from the definition above the writer concludes that numbered heads together is model of learning that every student are given a number and placed in groups for create a same perception or thought of students, then will be answered by what number is called by the teacher but the teacher calls a random number.

\section{b. The Procedures of Numbered Heads Togethe}

There are some procedures of numbered heads together, as a following:

\footnotetext{
${ }^{5}$ Arthur Hughes, Testing for Language Teachers, (USA: Cambridge University Press, 1990), p. 111.

${ }^{6}$ Muhammad Faturrahman, Model-Model PembelajaranInovatif, (Jogjakarta: Ar-Ruzz Media, 2015), P.82.
} 
1) The teacher delivers about the material and explains the rules.

2) Students are placed in groups and each person is given a number.

3) The teacher gives a question or task to the students.

4) The students put their heads together, discuss the correct answer, and make sure that everyone knows the answer.

5) The teacher calls a number and those students raise their hands to respond.

6) The responds of other group then the teacher calls other number.

7) Conclusion ${ }^{7}$.

From the explanation above, there were seven procedures of numbered heads together: deliver the material, placing students in groups, giving question, discussing, calling a number, responding, and conclusion.

\section{c. The Advantages of Numbered Heads Together}

There are some advantages of Number Head Together as follow:

1) Positive interdependence

The students are able to learn from each other. They must also work together to ensure there is one product to their learning. They must check that everyone can understand and answer the question.

2) Individual accountability

Students are accountable to each other for sharing ideas. The students may also be required to share their partner's ideas to another pair or whole group. Every student must be able to give the group response to the question.

3) Equal participation

Each student within the group has an equal opportunity to share. It is possible that one student may try to dominate. The teacher can check this does not happened.

\footnotetext{
${ }^{7}$ Ibid., p. 90.
} 
4) Simultaneous interaction

High degrees of interaction at any one moment all of the students will be actively engaged in purposeful speaking and listening.

5) Multilevel

This kind learning can be used in any kinds of level, but of course it has to be adjusted with the material given. ${ }^{8}$

From the explanation above, there were five advantages of numbered heads together: positive interdependence, individual accountability, equal participation, simultaneous interaction, and multilevel.

\section{d. The Disadvantages of Numbered Heads Together}

There are some disadvantages of Number Head Together as follow:

1) The smart student will tend to dominate so that it can make the weak students have interior and passive attitude.

2) The discussion process can go smoothly if there are students just simply copy the work of smart students without having an adequate understanding.

3) If there are homogenous group so it will be unfair for the group contained of weak students.

4) Likelihood that number is called, called again by the teacher, means that not all members of the group called by the teacher.

5) Not all members of the group are called by the teacher

6) Student's assessment is given based on their group work

7) Need a lot of time and sometimes class is not controlled ${ }^{9}$.

From the explanation above, that is concluded there are seven disadvantages of using numbered heads together strategy: the smart student will tend to dominate, the weak student will passive, The discussion process can go smoothly, If there are homogenous group so

\footnotetext{
${ }^{8}$ Mandal, R.R. Cooperative Leraning Strategies to Enhance Writing Skill. Lady Willing Don Institute of Advanced Study in Education, Chennai.In http://eprints.ums.ac.id/19644/14/02. Publication Article.pdf, retrived on $18^{\text {th }}$ November, Sunday, 15.30 .

${ }^{9}$ Dr. Hamdani, Op.Cit., p. 92.
} 
it will be unfair for the group contained of weak students, not all members of the group called by the teacher, need a lot of times and class is not controlled.

\section{E. The Research Design}

\section{The Research Kind}

Classroom action research included the social research purposely to improve the quality of something. The aim of classroom action research is to improve one's teaching practice or to enhance the functioning of school. Then, the research design of this research is follow action research spiral by Kemmis and Mc Taggart because this form is one of the best models as it summaries very succinctly the essential steps of the classroom action research process. Cyclical action research model based on the Kemmis and Mc Taggart concerns to four steps namely are planning, acting, observing, and reflecting.

\section{The Participants}

The participants in this research were all the students at grade XI IPA-1 in first semester of the academic year 2017/2018 SMA N 1 Batang Angkola. It consists of 23 students. They were 4 males and 19 females. This class was chosen because the researcher found the speaking problems in this class. Then, there was collaborate with an English teacher, Mr. Drs. Andi Hotman as an English teacher of SMA N 1 Batang Angkola.

\section{The Instrument of Collecting Data}

\section{a. Test}

In this research, the researcher used speaking test. The researcher gave the question then the students discussing the task with his group which was numbered heads together. Therefore, the students will be ordered by teacher to perform in front of the class orally. Because, the test was orally and to know the improvement of students' speaking ability, so the researcher has some indicators in speaking test by number heads together strategy, as follow:

1) Accent 

2) Grammar
3) Vocabulary
4) Fluency
5) Comprehension

\section{b. Observation}

The researcher used observation type field notes. Field notes is the observer record of what saw, hear, experiences and thought about during an observation session. ${ }^{10}$ The researcher observed all the condition that happen during the teaching and learning process, the researcher observed the teacher, students' activities during the learning teaching process and the factors which influence the teaching learning process in speaking by using numbered heads together strategy. In this observation researcher collaborated with an English teacher at grade XI IPA-1 in first semester of the academic year 2017/2018 SMA N 1 Batang Angkola.

\section{c. Interview}

Interview is to talk somebody and ask questions at a formal meeting to find out if he is suitable for job or study. ${ }^{11}$ The researcher used the interview to know the condition of the students. To know students' problem in speaking ability through numbered heads together strategy in the classroom, there were five should be measured from the students. They are:

1) The students' problem in accent

2) The students' problem in grammar

3) The students' problem in vocabulary

4) The students' problem in fluency

5) The students' problem in comprehension.

\footnotetext{
${ }^{10}$ L. R. Gay Peter, Educational Research: Competencies for Analysis and Application, (New York: Prentice Hall, 2000), p. 593.

${ }^{11}$ A. S. Hornby, Oxford advance learners dictionary (New York: oxford university press, 2000), p. 788 .
} 


\section{Procedures of the Classroom Action Research}

This action research used the model of Kemmis and Mc Taggart. That concerns to four steps namely are planning, acting, observing, and reflecting. ${ }^{12}$ The model is described in the following figure:

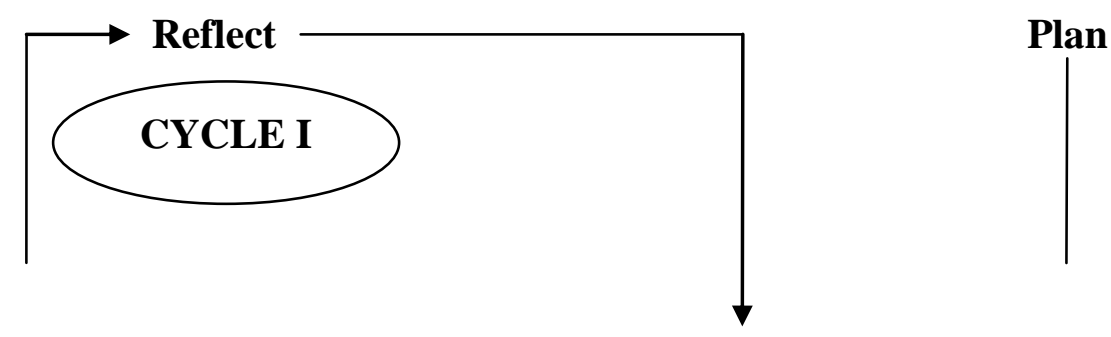

Act and observe

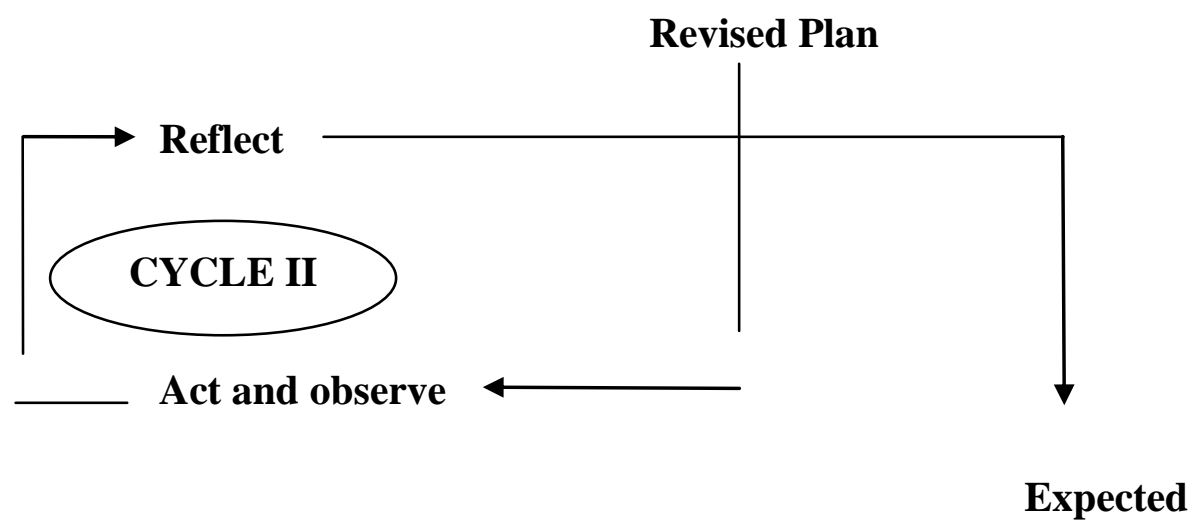

\section{Condition}

Figure 1. Action research spiral by Kemmis

It is applied in two cycles. Every cycle consists of two meeting and the time allocation is $2 \times 45$ minutes or 90 minutes. So, it needs 180 minutes for each cycle. The explanation of activities in teaching speaking ability through numbered heads together at grade XI in first semester of the academic year 2017/2018 SMA N 1 Batang Angkola.

\footnotetext{
${ }^{12}$ Anne Burns, Op.Cit.p. 9.
} 


\section{CONCLUSION}

From the result of this research can be concluded that:

1. The hypothesis is accepted, in other word that numbered heads together strategy improved students' speaking ability at grade XI SMA N 1 BatangAngkola with $52.17 \%$. It based on the mean score in which students' speaking skill in cycle 1 was $21.74 \%$ and became $73.91 \%$ in cycle 2. The students' improvement can be categorized into high improvement. Then, the calculation result of $t_{0}=47.32$, $\mathrm{t}_{\text {tablewith } \mathrm{df}}=22$, level of significance in $\mathrm{t}$ table $5 \%$ is 33.92 . It can be known that the result of $t_{0}$ is bigger than $t_{t}$, it is 47.32>33.92. Based on the result, it means that there is a significant improvement between students' speaking learning process result in the first cycle and second cycle.

2. Some factors that influence students' speaking ability by using numbered heads together strategy were accent, grammar, vocabulary, fluency and comprehension. The solutions of the problems are; researcher motivated them to be diligent in training their pronunciation, researcher teaching mostly about grammar, researcher gave some vocabularies related to the learning material before starting learning process, researcher ordered them to record their speech so that they could know about their ability and the last researcher tried to guess and improved researcher self to comprehend their retelling of result discussion well.

\section{REFERENCES}

Aqib, Zainal., PTK untuk Guru SMP, SMA, SMK (Bandung: CV. YramaWidya, 2008.

Brown, H. Douglas., Teaching by Principles an Interactive Approach to Language Pedagogy, USA: Prentice Hall Regents, 1994.

, Language Assessment Principles and Classroom Practice, San Francisco State University: 2004.

Bull,Victoria., Oxford Advance Learner's Dictionary Sixth Edition, (New York: Oxford University Press, 2008.

Burns, Anne., Doing Action Research in English Language Teaching, New York, 2010. 
Chaney, A. L and Burke, T. L.,Teaching Oral Communication in Grades K-8, Boston: Allyn \& Bacon, 1998.

Denzin, Norman k. \& Yvonna S. Lincoln, A Handbook of Qualitative Research, Translated by Dariyanto \& Friends, (Yogyakarta: Pustaka Pelajar, 2009.

Faturrahman, Muhammad ., Model-Model Pembelajaran Inovatif, Jogjakarta: Ar-Ruzz Media, 2015.

Gay, L. R. and Peter Airasian, Educational Research: Competencies for Analysis and Application, (New York: Prentice Hall, 2000.

Hamdani, Strategy Belajar Mengajar, Bandung: Pustaka Setia, 2011.

Harmer, Jeremy., The Practice of English Language Teaching, London: Longman, 2001.

Hartono, Statistic:untuk Penelitian, Yogyakarta: Pustaka Pelajar Offset, 2004.

Hornby, A. S., Oxford Advance Learners Dictionary (New York: Oxford University Press, 2000.

Hughes,Arthur., Testing for Language Teachers, USA: Cambridge University Press, 1990.

Istarani, 58 Model Pembelajaran Inovatif, Medan: CV “ISCOM”, 2014.

Mandal, R.R. Cooperative Learning Strategies to Enhance Writing Skill. Lady willing Don Institute of Advanced Study in Education, Chennai. InSunday, 15.30.

Neufeldt, Victoria., Webter New Collage Dictionary-3rd, New York: Simon \&SchuterIne, 1995.

Nunan, David.,Practical English Language Teaching, New York: McGraw-Hill Companies, 2003.

O’Malley, J.Michael., Authentic Assessment for English Language Learners, USA: Addison-Wesley Publishing Company, 1996.

Richards, Jack. C., curriculum development in language teaching, (New York: Cambridge University Press.

Ridwan, Belajar Mudah Penelitian untuk Guru-Karyawan \& Penelitian Pemula, Bandung: Penerbit Alfabeta, 2012.

Slavin, Robert E., Cooperative Learning Theory, Research, \& Practice Second Edition, USA: Library of Congress Catalonging in Publication Data, 1995. 